WSRC-TR- $-92-304$

DE93 005076

\title{
Results of the First Quarter Tritium Survey of the F- and H-Area Seeplines: May 1992 (U)
}

\author{
K. L. Dixon and V. A. Rogers \\ Westinghouse Savannah River Company \\ Savannah River Site \\ Aiken, SC 29808
}

\section{MHSTER}

Prepared for the U. S. Department of Energy under contract No. DE-AC09-89SR18035 


\title{
Results of the First Quarter Tritium Survey of the F- and H-Area Seeplines: May 1992
}

\author{
K. L. Dixon and V.A. Rogers
}

\section{Executive Summary}

In May 1992 the Environmental Sciences Section (ESS) surveyed the Four Mile Creek seepline down gradient from the $\mathrm{F}-$ and $\mathrm{H}$-Area seepage basins for tritium, specific conductivity, and $\mathrm{pH}$. The survey was the first of four quarterly surveys for monitoring the movement of contaminants from the basins since closure. Surface-water samples were collected from 51 locations along the seepline; Haselow et al. (1990) sampled 44 of the locations and 7 were newly established on the seepline south of 643-E, which is a decommissioned area in the Solid Waste Disposal Facility.

Results indicate that rainfall is diluting the contaminant plume that leached from the seepage basins and washing the plume out of the wetland systems below the basins. ESS found tritium activities in the F- and H-Area seeplines significantly lower than the concentrations measured by Haselow et al. (1990). Conductivity measurements exhibited the same trends as tritium activities in both areas, indicating that salt ions are also being removed from the wetland system. Concentrations of hydrogen ion also decreased in both areas, which indicates that conditions are changing from acidic to more natural $\mathrm{pH}$ values $(\mathrm{pH} \mathrm{5-6)}$.

The seepline south of 643-E exhibited signs of impact by tritium from the burial grounds. Tritium activities ranged from 35 to $1306 \mathrm{pCi} / \mathrm{ml}$, and condictivity values were near background levels. That is consistent with the wastes introduced into 643-E, which contained low levels of salt ions compared to the F- and H-Area basins. This suggests that seepline tritium in this area emanates from 643-E.

The results suggest that contaminant concentrations are decreasing at the F- and H-Area seeplines. Areas of stressed vegetation may start showing signs of recovery as contaminant concentrations decrease and $\mathrm{pH}$ increases. As $\mathrm{pH}$ increases above 4.0, areas exhibiting stress due to aluminum toxicity should begin recovery because the increase in $\mathrm{pH}$ (to about neutral) will reduce the solubility of the soil aluminum. Field observations indicate that several stressed areas show signs of recovery, particularly at the H-Area seepline.

\section{Introduction}

Seepage basins in the $F$ and $H$ Area of SRS received low-level radioactive-waste effluent from the chemical separation processes in the General Separation Areas (GSA). The basins retained the effluent to delay its release to the environment. The waste effluent consisted principally of sodium hydroxide, nitric acid, low levels of various radionuclides, and some metals (Killian et al., 1985a and b). Discharges of tritiated water to the seepage basins account for most of the radioactivity (Fenimore and Horton, 1972).

The Savannah River Laboratory (now the Savannah River Technology Center) conducted an extensive study aimed at characterizing the groundwater outcropping into Four Mile Creek and its associated seepline in 1988 and 1989 (Haselow et al. 1990). As a part of this study, Haselow et al. surveyed for tritium, $\mathrm{pH}$, and conductivity. Researchers measured low $\mathrm{pH}$ values, elevated conductivity, and tritium values along the seeplines and detcimined that contaminants leaching from the $\mathrm{F}$-and $\mathrm{H}$-Area seepage basins were impacting the areas.

SRS stopped discharges to the seepage basins in 1988 and capped and scaled the basins in 1990 to reduce the release of the contaminants. Scientists hypothesized that after eliminating the contaminant source, annual rainfall amounts and natural groundwater flow would dilute and flush out the remaining contaminant plume over time. After the contaminant plume is diluted and flushed out, the wetland systems below the basins should begin to recover.

To investigate this hypothesis, a quarterly sampling program was established. ESS sampled 44 of the seepline locations sampled by Haselow et al. (1990) for tritium, pH, 
and specific conductivity. This sampling program is intended to compliment semiannual sampling of the seepline for Resource Conservation Recovery Act Appendix IX characterization, which is scheduled to begin in July 1992.

The Environmental Protection Department expressed concern about possible seepage of tritium and other contaminants from 643-E. To investigate this possibility, seven new locations on the H-Area seepline south of 643-E were sampled.

\section{Methods}

ESS conducted the first round of sampling in the quarterly tritium survey in May 1992. Sampling locations were selected that, according to 1989 data, exhibited high and low values for the three variables of concern. Attempts were made to establish even ground coverage along both seeplines. ESS collected 51 samples along the seeplines in $F$ and $H$ Area: 22 along the $F$-area seepline, 22 along the H-Area seepline, and 7 new locations on the H-Area seepline south of 643-E. Figures 1 and 2 show the sampling locations.

Prior to sampling, the Health Protection Department (HPD) collected and monitored soil samples from several locations along both seeplines for gamma radioactivity. HPD did not detect measurable levels of gamma radiation, and protective clothing was chosen based on the findings. During sampling operations in the seepline areas, protective clothing consisted of rubber boots and disposable rubber gloves. These measures were intended to prevent dermal contact with seepline water.

Seepline sampling locations were marked and labeled previously with PVC stakes. Water samples were collected within a $3 \mathrm{ft}$ radius of the PVC stake by either collecting surface water when present or by boring a hole into the soil with a 3.5 inch soil auger until water was reached. Polyethylene sample containers $(25 \mathrm{ml})$ were dipped into the water until full and capped them to collect water for tritium analysis. The outside of each container was then rinsed with deionized water and sealed in a small polyethylene bag to minimize the possibility of contamination. The small bags were then placed in a large polyethylene bag, which was sealed for analysis. The Environmental Monitoring Section (EMS) performed tritium analysis. EMS counted aliquots of $5 \mathrm{ml}$ for 20 minutes, which yielded a lower detection limit of $1.2 \mathrm{pCi} / \mathrm{ml}$.

ESS measured specific conductivity and $\mathrm{pH}$ in-situ with conductivity and pH electrodes (WSRC-L14.1, 1992a and 1992b). The electrodes were rinsed with deionized water after each sampling and thoroughly rinsed all sampling equipment with water at the end of each day.

\section{Results and Observations}

Concentrations of variables measured at seepline sampling locations fluctuate throughout the year. Climate, especially rainfall, influences measured concentrations. Low rainfall for a few mouths prior to sampling could create a concentration of constituents, and high rainfall amounts could dilute the constituents at the seepline intercept. Rainfall measured at SRS at the weather station in F-Area from January to May 1992 was $16.41 \mathrm{~cm}$. Long-term average rainfall amounts were not available for $\mathrm{F}$-Area. However, for the A and M Areas for 1960-1991, the average monthly rainfall from 1960-1991 through the month of May was $21.14 \mathrm{~cm}$. This indicates that for the first-quarter tritium survey, rainfall amounts in $F$ and $H$ Area may be slightly below normal. This should be considered when interpreting the survey results.

Figures 3 through 8 show comparisons of 1989 and 1992 tritium, conductivity, and $\mathrm{pH}$ measurements. Figures 9 through 11 show the data for the new locations on the seepline south of 643-E in $\mathrm{H}$ Area. The new sampling locations were assigned the identification prefix FHB.

\section{Tritium Measurements}

\section{F Area}

Tritium values in the F-Area seepline ranged from 11 to $9359 \mathrm{pCi} / \mathrm{ml}$ (see Table 1 and Figure 3). Of the 22 sampling locations in F Area, only 4 had tritium activities that exceeded the 1989 measurements. No values exceeded the maximum value recorded in 1989 of $14,000 \mathrm{pCi} / \mathrm{ml}$. The graphs in Figure 3 show that the tritium activity in most sampling locations either decreased significantly or remained relatively unchanged.

To investigate the hypothesis that the 1992 tritium activities are significantly less than in 1989, ESS conducted a Wilcoxon signed-rank test. The Wilcoxon signed-rank test uses the sign and the magnitude of the rank of the differences between pairs of measurements to compare nonparametric data. This test was chosen because it allows comparisons of paired data without assumptions of normality. The results showed that the 1992 concentrations were significantly less $(P=0.05)$ than the 1989 concentrations. 
Generally, the locations with the greatest decrease in tritium activity are closest to the seepage basins. In contrast, those further away show little change or even an increase in tritium activities. These changes indicate that the bulk of the tritium plume passed the locations closest to the seepage basins and is exiting the wetland system at the points closest to Four Mile Creek. This supports the general hypothesis that annual rainfall amounts would dilute the remainder of the contaminant plume emanating from the seepage basins. However, with only first-round data available, final conclusions cannot be drawn. ESS will evaluate the hypothesis after further sampling.

\section{H Area}

Tritium values in the $\mathrm{H}$-Area seepline ranged from 7 to $14,515 \mathrm{pCi} / \mathrm{ml}$ (see Table 2 and Figure 4). Of the 22 sampling locations, tritium activities in only 4 locations exceeded the 1989 values. The graphs in Figures 5 and 6 show that most locations have either decreased or have remained relatively unchanged. Of the 4 locations showing an increase, only HSP103 increased dramatically.

To investigate the hypothesis that 1992 tritium activities are significantly less than in 1989, ESS conducted a Wilcoxon signed-rank test. This test was chosen because it allows comparisons of paired data without assumptions of normality. The results showed that the 1992 concentrations were significantly less $(\mathrm{P}=0.05)$ than the 1989 concentrations.

ESs found the tritium activities in H-Area sampling locations nearest to seepage basin decreased the most, which is consistent with F Area. The activity at locations further away had a smaller decrease or increased. These changes indicate that the bulk of the tritium plume passed the locations closest to the seepage basins and is exiting the wetland system at the points closest to the creek.

\section{Conductivity Measurements}

\section{F Area}

Conductivity measurements in the F-Area seepline ranged from 28 to $1454 \mu \mathrm{S} / \mathrm{cm}$ (see Table 1 and Figure 5). Due to the extreme variability of conductivity measurements, ESS only considered differences of $100 \mu \mathrm{S} / \mathrm{cm}$ or more as meaningful. Of the 22 sampling locations in the F-Area seepline, only 2 had measurements of more than $100 \mu \mathrm{S} / \mathrm{cm}$ above the 1989 measurements. These two locations coincide with two of the locations with tritium activities elevated above the 1989 measurements. At the other two locations with elevated tritium activities, one location had slightly higher conductivity than in 1989, and the other had a conductivity value considerably lower than in 1989. A comparison of the graphs in Figures 3 and 5 shows that conductivity follows the same general trends as the tritium activities. ESS expected this similarity because tritium traces the movement of the contaminant plume from the basins (Haselow et al. 1990). These results suggest that the salt ions are also exiting the wetland system in F Area.

\section{H Area}

Conductivity measurements in the $\mathrm{H}$-Area seepline ranged from 36 to $505 \mu \mathrm{S} / \mathrm{cm}$ (see Table 2 and Figure 6). Of the 22 sampling locations, only 1 had measurements of thore than $100 \mu \mathrm{S} / \mathrm{cm}$ above the 1989 measurements. That sampling location coincides with a sampling location with elevated tritium activities. $\mathrm{H}$-Area measurements map well with tritium activities, which is consistent with F Area.

Conductivity measurements at sampling location HSP103 remained relatively unchanged and are at background levels; however, tritium activities are elevated. This supports the conclusions drawn by Haselow et al. (1990) that while conductivity values down gradient of 643-E remain near background, tritium values are elevated due to tritiated waste deposited in 643-E. Materials disposed in 643-E would not produce high specific conductivity values. This indicates that tritium activities measured at HSP103 continue to be influenced by seepage from 643-E.

\section{$\mathrm{pH}$ Measurements}

F-Area $\mathrm{pH}$ values ranged from 2.9 to 5.9 with an average value of 5.03 (Table 1 and Figure 7). Due to instrument malfunction, $\mathrm{pH}$ values for locations FSP226 and FSP235 were not obtained. H-Area $\mathrm{pH}$ values ranged from 4.6 to 6.6 with an average of 5.9 (Table 2 and Figure 8 ). The $\mathrm{pH}$ for the entire seepline ( $F$ and $H$ combined) averaged 5.5. The average increased 0.6 units over the 4.9 avcrage in 1989 (Haselow et al. 1990). While the average $\mathrm{pH}$ remains in the acidic range, the fourfold decrease in hydrogen ion concentration indicates that the contaminant plume is exiting the system. The increase in $\mathrm{pH}$ will affect the solubility of metals in the soil profile, which enhances recovery of areas stressed by low $\mathrm{pH}$. Those areas exhibiting aluminum toxicity due to aluminum leaching from the soil profile (as a result of low $\mathrm{pH}$ ) should start showing signs of recovery. Field observations of several stressed areas support this conclusion. 


\section{Solid Waste Disposal Facility (643-E) Seepline Results}

The graphs in Figures 9-11 show tritium, conductivity, and $\mathrm{pH}$ values for the new seepline sampling locations south of 643-E, which is in the Solid Waste Disposal Facility. Table 3 provides the data used in the figures.

Tritium activities for the area range from 35 to $1306 \mathrm{pCi} / \mathrm{ml}$. While the rritium activities are slightly elevated, they are generally not as high as most $\mathrm{F}$ - and $\mathrm{H}$-Area seepline concentrations. As mentioned earlier, since conductivity readings are low for these sampling locations, tritium activities measured at this seepline are probably emanating from 643-E.

Conductivity measurements ranged from 28 to $57 \mu \mathrm{S} / \mathrm{cm}$. This range is near background levels and instrument detection limits.

Values of $\mathrm{pH}$ range from 4.6 to 5.0 with an average of 4.8 .

\section{Conclusions}

Preliminary results from the first quarter tritium survey indicate that the contaminant plume migrating from the Fand $\mathrm{H}$-Area seepage basins is beginning to exit the wetland system down gradient from the basins. ESS attributes this to the closure and capping of the basins, which eliminated the hydraulic head driving the contaminants out of the basin. WSRC scientists hypothesized that after the basins were capped, annual rainfall amounts would dilute and flush out the remaining contaminant plume. The first quarter tritium survey results appear to support this hypothesis. However, with only first-round data available, ESS cannot draw final conclusions. The hypothesis will be evaluated after further sampling.

Evaluation of data from several new seepline locations south of the 643-E facility indicates that tritium seepage from $643-E$ is impacting the seepline slightly. However, tritium activities measured on the seepline are well below maximum 1992 concentrations measured for both the F-and H-Area seeplines.

\section{References}

Fenimore, J.W, J.H. Horton. 1972. Rating History and Environmental Effects of Seepage Basins in Chemical Separations Areas of the Savannah River Plant. DPST-72-548, Savannah River Laboratory, Aiken, SC.

Haselow, J.S., M. Harris, B.B. Looney, N.V. Halverson, J.B. Gladden. 1990. Analysis of Soil and Water at the Four Mile Creek Seepline Near the F and H Area of SRS (U). WSRC-RP-90-0591, Savannah River Laboratory, Aiken, SC.

Killian, T.H., N.L. Kolb, P. Corbo, I.W. Marine. 1985a. FArea Seepage Basins. DPST-85-704, Savannah River Laboratory, Aiken, SC.

Killian, T.H., N.L. Kolb, P. Corbo, I.W. Marine. 1985b. HArea Seepage Basins. DPST-85-706, Savannah River Laboratory, Aiken, SC.

WSRC-L14.1. 1992a. Procedure for Cole-Parmer Portable Conductivity Meter Model 1481-40. Procedure 2-79, Rev. 0. Westinghouse Savannah River Company, Aiken, SC.

WSRC-L14.1. 1992b. Procedure for Cole-Parmer Model 5985-80 pH Meter. Procedure 2-81, Rev. 0. Westinghouse Savannah River Company, Aiken, SC. 


\section{Figures}

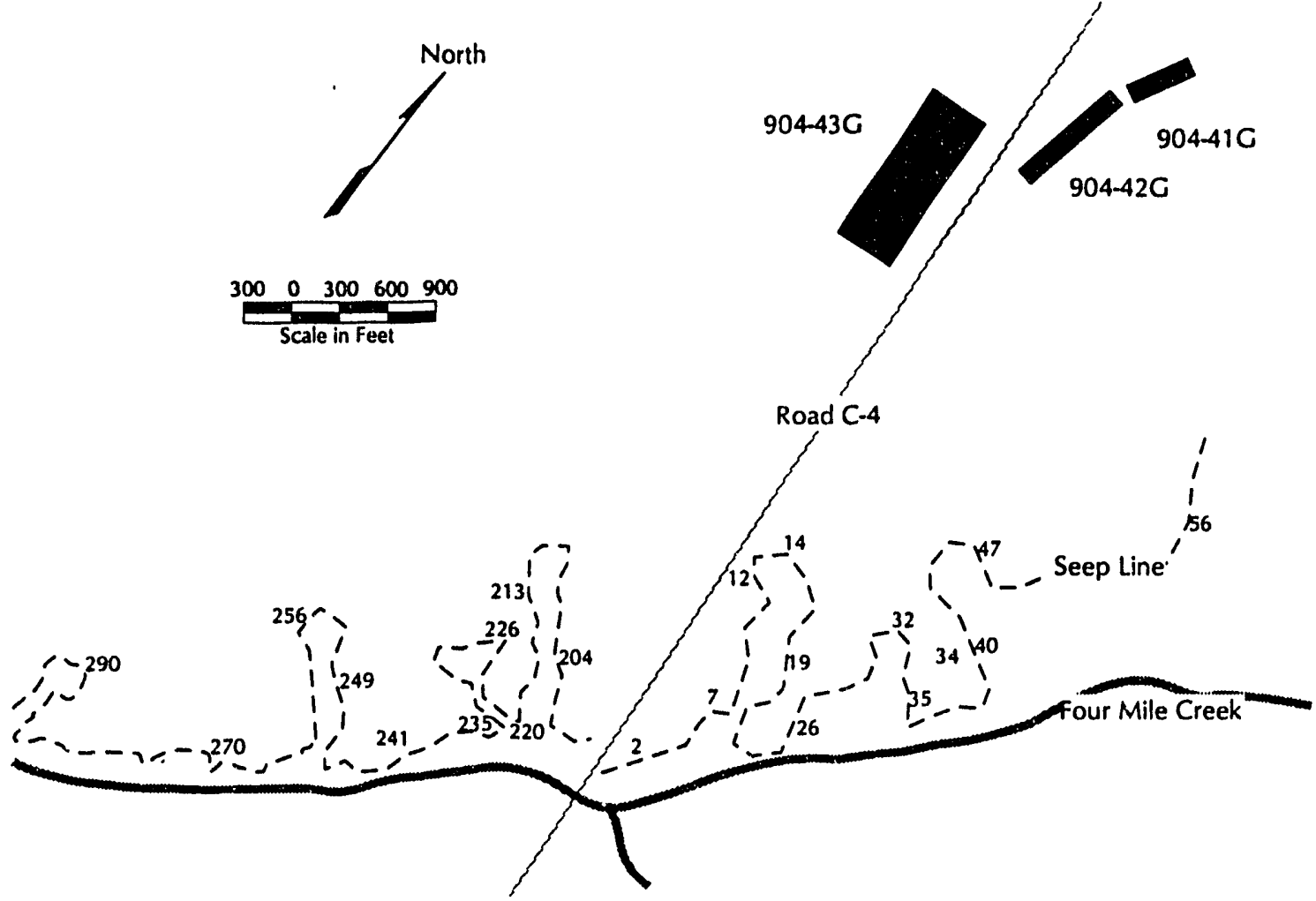

Figure 1. Location of F-Area Seepage Basins and Seepline Sampling Points

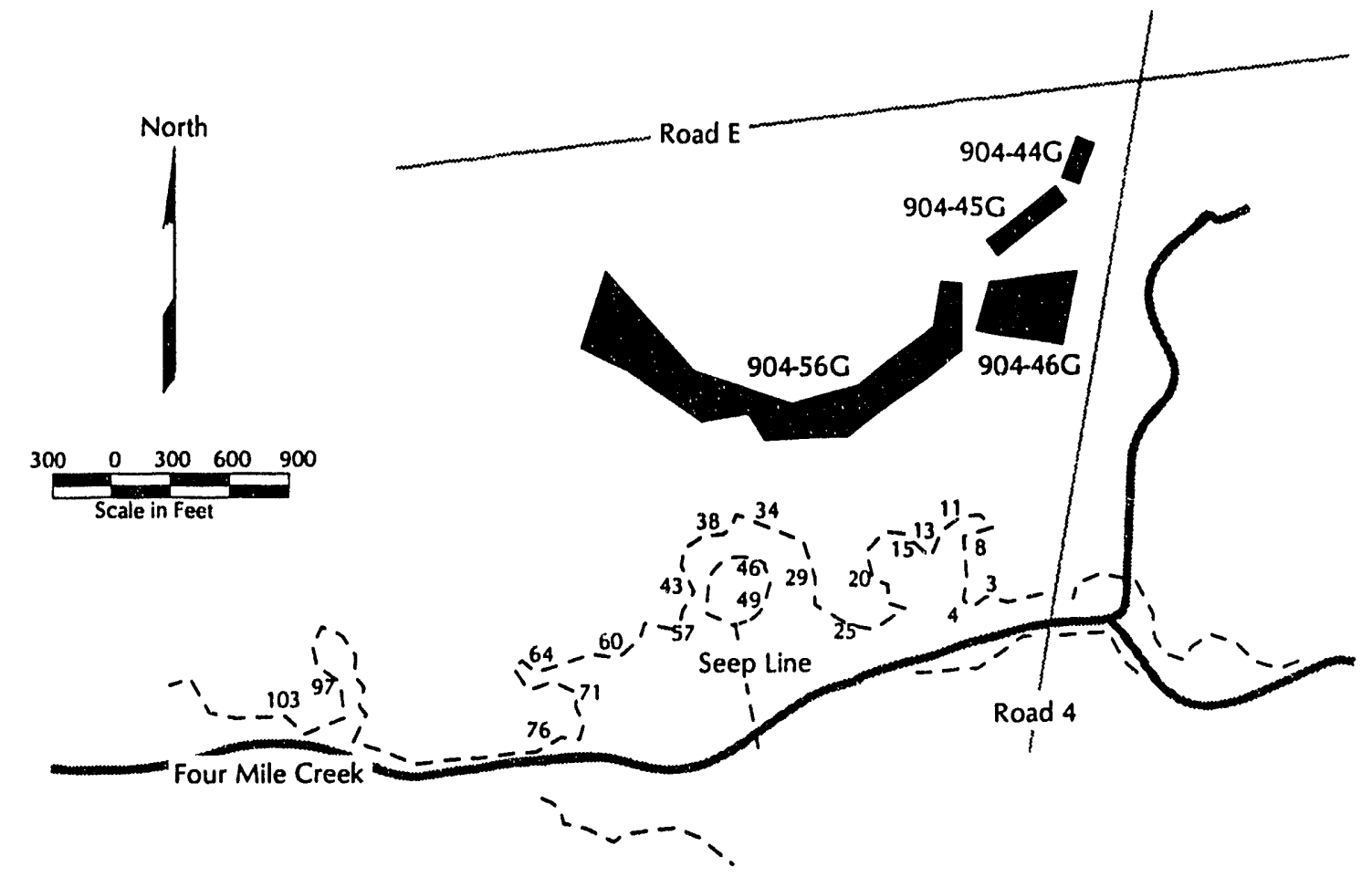

Figure 2. Location of H-Area Seepage Basins and Seepline Sampling Points 


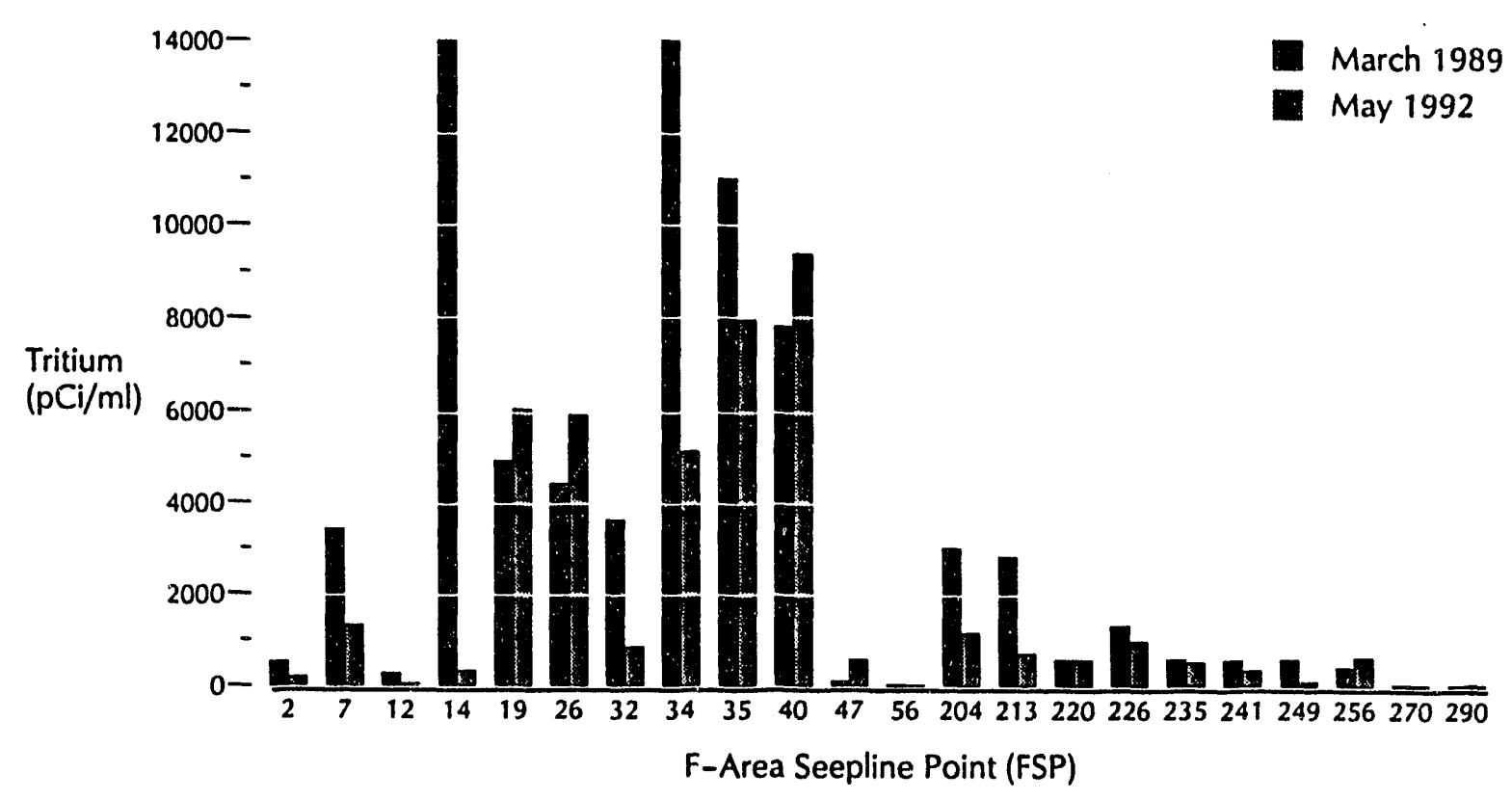

Figure 3. Comparison of 1989 and 1992 Tritium Concentrations for Selected F-Area Seepline Locations

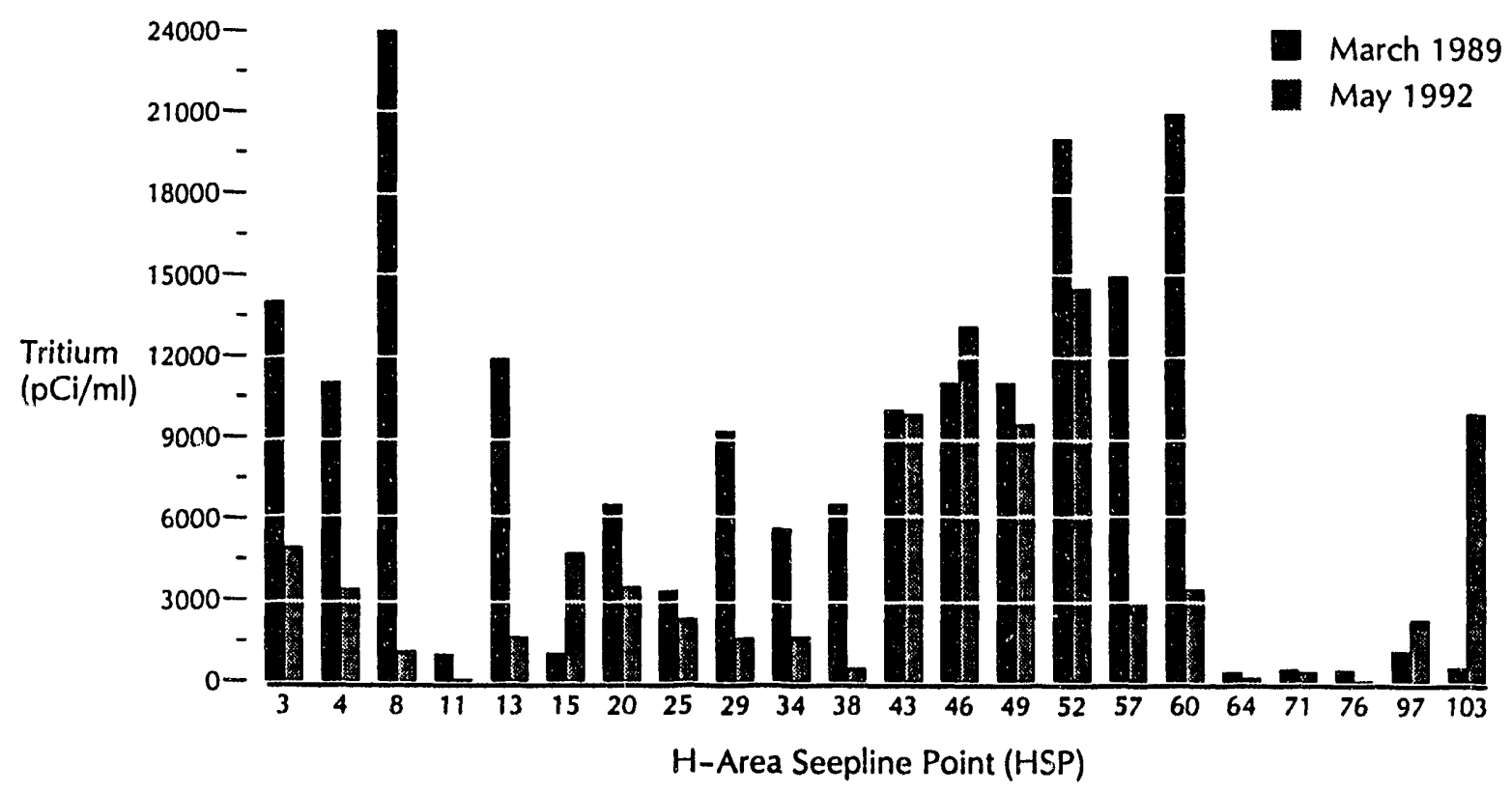

Figure 4. Comparison of 1989 and 1992 Tritium Concentrations for Selected H-Area Seepline Locations 


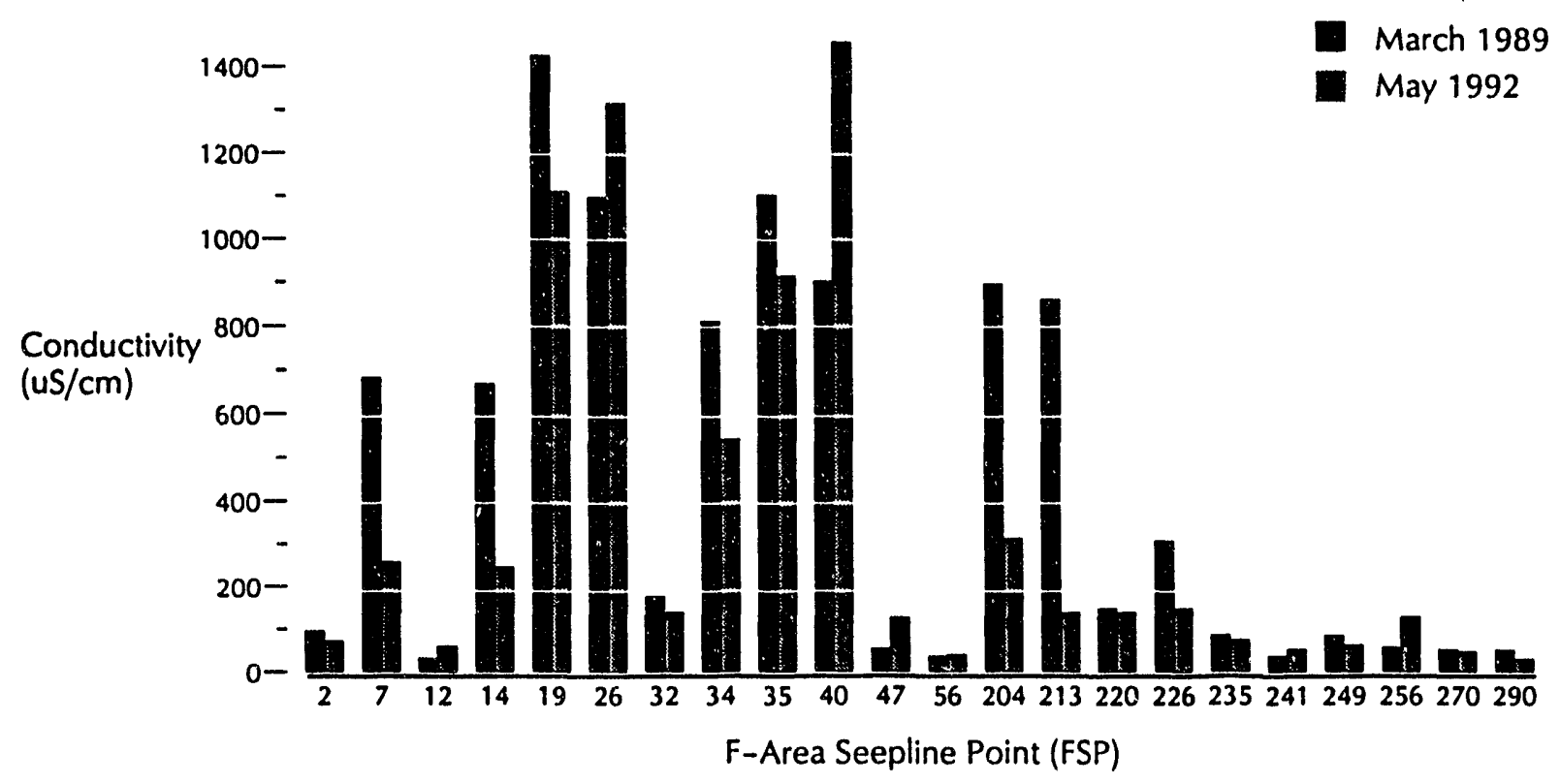

Figure 5. Comparison of 1989 and 1992 Conductivity Measurements for Selected F-Area Seepline Locations

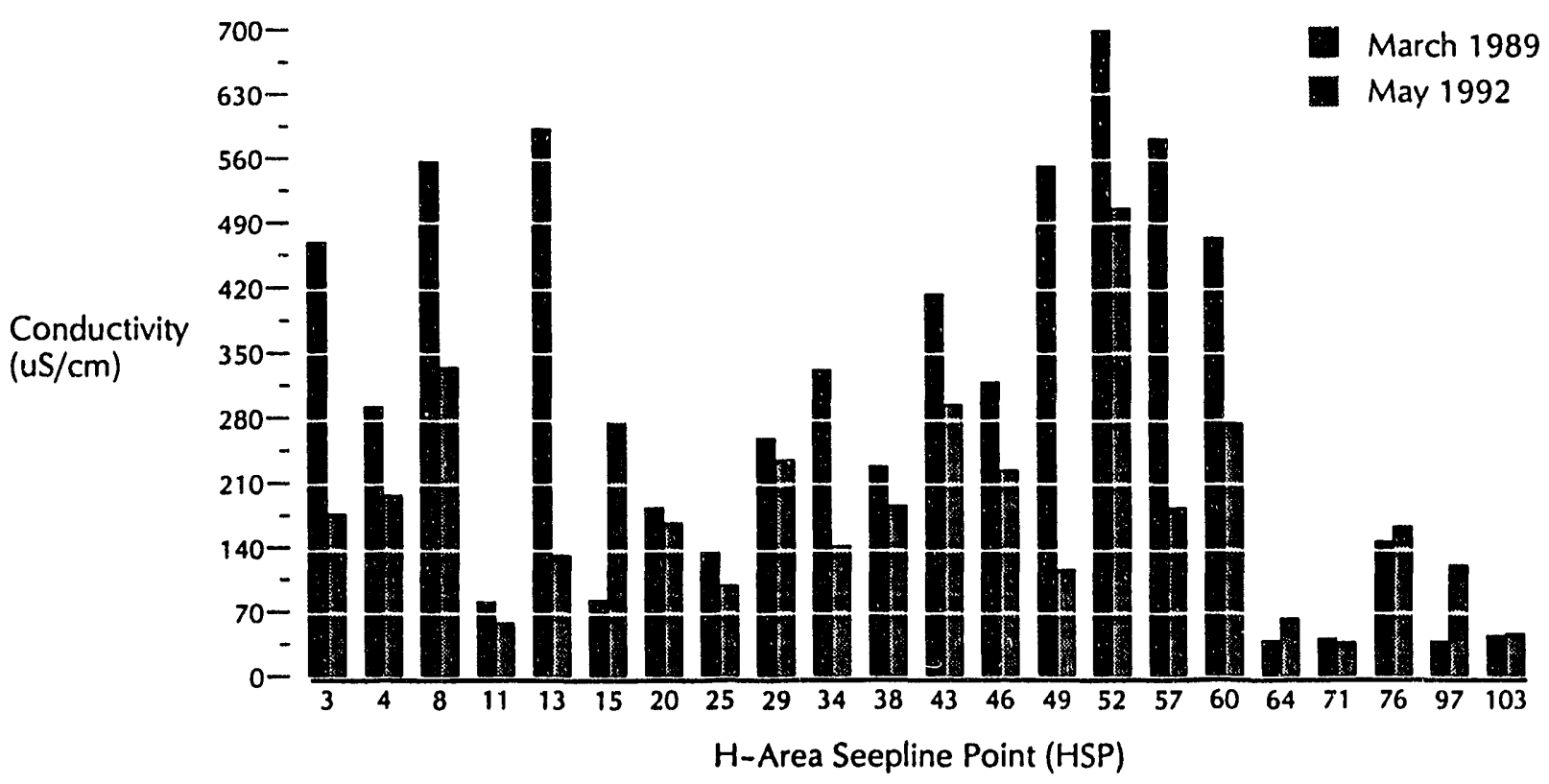

Figure 6. Comparison of 1989 and 1992 Conductivity Measurements for Selected H-Area Seepline Locations 

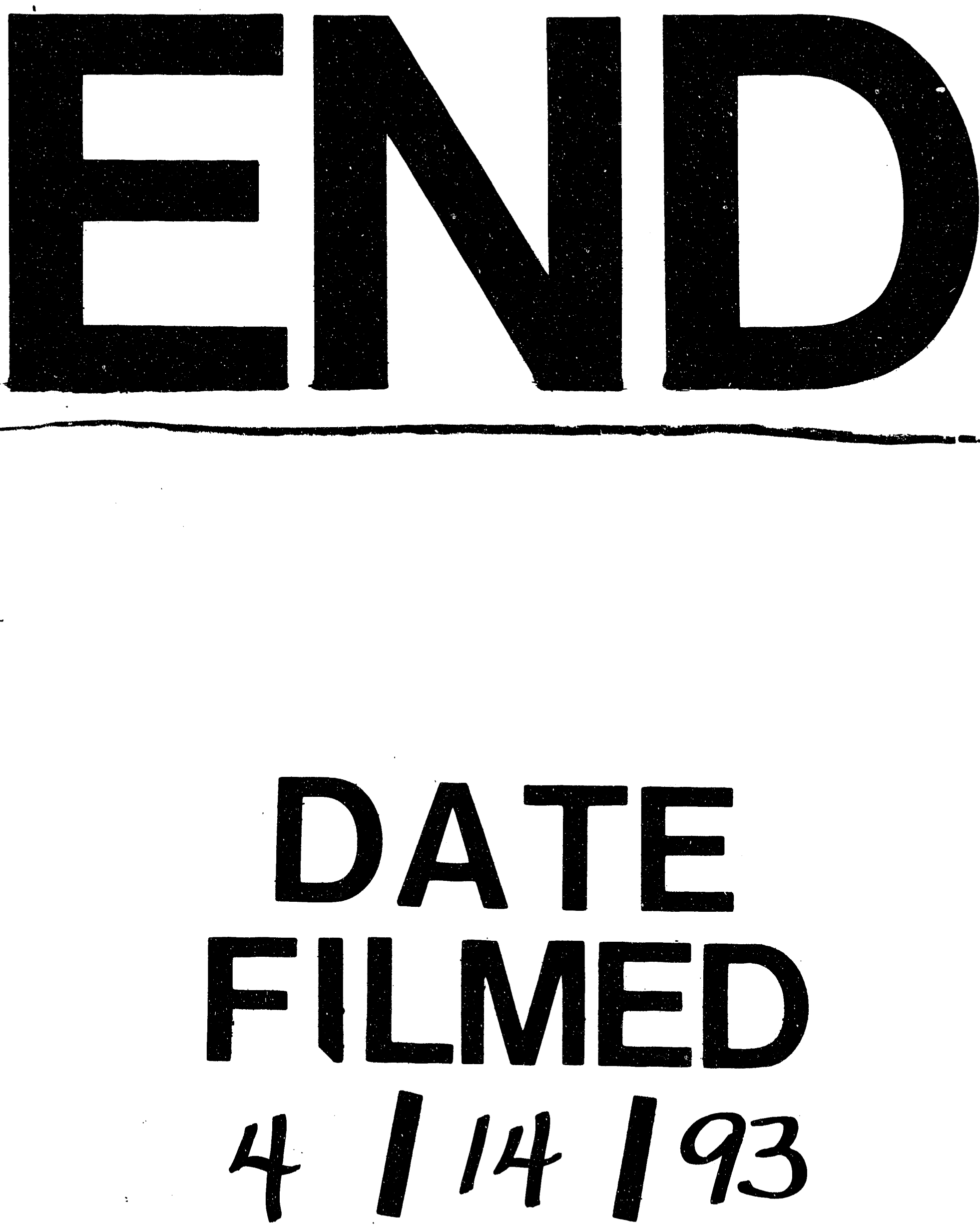
